\title{
PENERAPAN MODEL NUMBERED HEADS TOGETHER PADA KOMPETENSI DASAR KEADAAN SOSIAL NEGARA TETANGGA DALAM MENINGKATKAN HASIL BELAJAR IPS SISWA KELAS VI SD NEGERI 060819 MEDAN KOTA
}

\author{
Onike Naibaho \\ Surel: onikenaibaho@gmail.com
}

\begin{abstract}
ABSTRAK
Penelitian ini bertujuan untuk meningkatkan hasil belajar IPS siswa kelas VI SD Negeri 060819 Medan Kota melalui model pembelajaran Numbered Heads Together. Jenis penelitian ini adalah tindakan kelas (PTK). Subjek dalam penelitian ini adalah siswa kelas VI yang berjumlah 27 orang. Hasil penelitian menunjukan pada saat pre tes diperoleh dari 27 orang siswa, 4 siswa $(14,81 \%)$ yang memenuhi ketuntasan belajar dan 23 siswa $(85,18 \%)$ tidak memenuhi ketuntasan belajar dengan nilai rata-rata 42,74 , selanjutnya pada siklus I diperoleh nilai rata-rata kelas meningkatkan sebanyak 25,14 (dari $42,74$ naik menjadi 67,88$)$, dengan sebanyak 16 siswa $(59,25 \%)$ yang memenuhi ketuntasan belajar dan 11 siswa (40,74\%) tidak memenuhi ketuntasan belajar. Pada siklus II meningkat menjadi 84,22 dengan sebanyak 24 siswa $(88,88 \%)$ yang memenuhi ketuntasan belajar dan 3 siswa $(11,11 \%)$ tidak tuntas. Jadi dapat dikatakan pada siklus II ketuntasan belajar meningkat sebesar 16,34 (dari 67,88 naik menjadi 84,22). Dengan demikian dapat disimpulkan bahwa penggunaan model pembelajaran Numbered Heads Together dapat meningkatkan hasil belajar siswa di Kelas VI SD Negeri 060819 Medan Kota tahun ajaran 2017/2018.
\end{abstract}

Kata Kunci: Hasil Belajar, IPS, Model Numbered Heads Together

\section{PENDAHULUAN}

Pembelajaran IPS merupakan pembelajaran yang sangat penting bagi siswa yang berkaitan langsung dengan interaksi siswa dengan lingkungannya yang beragam situasi dan kondisi. Dalam kegiatan pembelajaran IPS pada siswa dimulai dengan memperkenalkan pengetahuan yang berhubungan dengan kehidupan sehari-hari, dan dihadapkan pada berbagai permasalahan yang ada dan terjadi di lingkungan sekitarnya. Dengan demikian siswa akan akrab dengan kondisi setempat sehingga mengetahui makna serta manfaat mata pelajaran IPS nyata.

Dalam pembelajaran IPS siswa merasa kesulitan memahami jenis materi tertentu yang menyebabkan dalam pembelajaran kurang tercapainya suatu kompetensi dasar yang seharusnya itu merupakan satu tujuan yang diinginkan oleh setiap pendidik. Bila pembelajaran IPS hanya didominasi dengan metode ceramah maka mata pelajaran IPS dapat menjadi mata pelajaran yang

SD Negeri 060819 Medan Kota 
membosankan bagi siswa, karena mereka tidak secara langsung mengetahui dari apa yang didengarnya. Yang menyebabkan antara siswa dan pendidik tidak terjadi interaksi yang aktif, bertukar informasi, bicara dan mengemukakan pendapat.

Masih rendahnya minat belajar siswa dapat diketahui pada saat pembelajaran berlangsung dengan diamati dari bagaimana aktivitas siswa saat mengikuti pembelajaran, interaksi antar guru siswa, interaksi antar siswa dapatmengakibatkan hasil belajar IPS yang belum optimal (rendah). Disamping itu pembelajaran masih dominan menggunakan metode ceramah sehingga sebagian besar masih pasif dan pembelajaran hanya berpusat pada guru.

Materi IPS tidak selalu dapat kita pelajari secara langsung, apabila jika kita ingat bahwa sebagian dari proses pembelajaran IPS tidak selamanya dilakukan di dalam kelas. Hal-hal yang tidak dapat diamati dan dipelajari sesuai dengan keadaan aslinya sehingga memerlukan alat atau perantara sebagai media. Kelas dapat dijadikan sumber pembelajaran sangat bergantung kepada guru dalam melaksanakan perannya sebagai pengelola kelas.

Berdasarkan kenyataan saat ini, hasil belajar siswa terhadap pelajaran IPS sangat rendah, dikarenakan siswa menganggap bahwa pelajaran IPS itu membosankan, kurangnya keaktifan siswa dalam mengikuti pembelajaran IPS dan masih terdapat siswa yang mencari kesibukan lain seperti bermain dan mengganggu temannya di dalam kelas. Selain itu, pembelajaran IPS di kelas masih cenderung monoton, sehingga kurang menarik minat belajar siswa.

Berdasarkan observasi awal yang guru lakukan di kelas VI SD Negeri 060819 Medan Kota. khususnya dalam pelajaran IPS menunjukan bahwa interaksi pembelajaran dalam kelas masih berpusat pada guru dan masih menggunakan metode ceramah, tanya jawab serta tidak menggunakan media dalam proses belajar mengajar dan siswa begitu saja menerima informasi yang diberikan guru. Padahal keberhasilan siswa dalam belajar bergantung pada aktifitas belajar siswa selama proses belajar mengajar berlangsung.

Penggunaan model pembelajaran yang kurang tepat merupakan salah satu penyebab rendahnya hasil belajar siswa Kelas VI SD Negeri 060819 Medan Kota, khususnya pada mata pelajaran IPS. Maka dari itu, seorang guru harus mampu menyusun pembelajaran yang membuat siswa aktif dalam belajar.

Dari permasalahan di atas maka perlu adanya upaya perbaikan 
hasil belajar siswa, salah satunya dengan cara memilih model pembelajaran yang sesuai dengan materi yang disampaikan. Peneliti memilih model pembelajaran Numbered Heads Together. Model pembelajaran ini dapat memacu siswa dalam menelaah materi yang tercakup dalam suatu pelajaran dan pemahaman mereka terhadap isi pelajaran.

Berdasarkan uraian-uraian di atas, maka guru mengajukan judul "Penerapan Model Numbered Heads Together Pada Kompetensi Dasar Keadaan sosial negara-negara tetangga Pelajaran IPS Dalam Meningkatkan Hasil Belajar Siswa Kelas VI SD Negeri 060819 Medan Kota. Tahun Ajaran 2017/2018”.

Berdasarkan latar belakang masalah yang telah diuraikan di atas, maka dapat diidentifikasi beberapa masalah sebagai berikut:

1. Hasil belajar siswa sangat rendah terhadap pelajaran IPS.

2. Siswa merasa jenuh dan bosan terhadap pelajaran IPS.

3. Rendahnya minat belajar siswa terhadap pelajaran IPS dapat diketahui pada saat pembelajaran berlangsung.

4. Guru hanya menggunakan metode ceramah dan tanya jawab dalam proses belajar mengajar.

5. Guru kurang menggunakan media dalam proses belajar mengajar.
Penelitian ini bertujuan untuk meningkatkan hasil belajar siswa dengan menggunakan model Numbered Heads Together pada pelajaran IPS materi pokok keadaan sosial negara-negara tetangga di Kelas VI SD Negeri 060819 Medan Kota tahun ajaran 2017/2018.

\section{METODE PENELITIAN}

Jenis penelitian yang dilakukan adalah penelitian tindakan kelas (PTK) yang bertujuan untuk memperbaiki dan meningkatkan hasil belajar dalam proses pembelajaran siswa pada pelajaran IPS dengan menerapkan model Numbered Heads Together di Kelas VI SD Negeri 060819 Medan Kota.

Penelitian dilakukan pada siswa Kelas VI SD Negeri 060819 Medan Kota tahun ajaran 2017/2018 dan waktu pelaksanaan Penelitian Tindakan Kelas pada semester ganjil Tahun Ajaran 2017/2018 selama 3 bulan.

Subjek penelitian dalam tindakan Kelas VI ini adalah siswa Kelas VI SD Negeri 060819 Medan Kota tahun ajaran 2017/2018 yang berjumlah 27 orang siswa. Objek penelitian dalam penelitian tindakan Kelas VI ini adalah "Menggunakan model Numbered Heads Together untuk meningkatkan hasil belajar siswa pada pelajaran IPS materi pokok keadaan sosial negara-negara tetangga". 
Penelitian ini memiliki beberapa tahapan pelaksanaan yang dilangsungkan didalam kelas, meliputi pelaksanaan PTK berupa refleksi awal dan observasi untuk mengidentifikasi permasalahan yang terjadi di kelas. Pada penelitian ini, peneliti dibantu oleh seorang guru dalam mengidentifikasi dan mencari permasalahan-permasalahan dalam pembelajaran IPS pada materi Keadaan sosial negara-negara tetangga pada siswa Kelas VI SD Negeri 060819 Medan Kota tahun ajaran 2017/2018.

Peneliti melaksanakan penelitian dengan desain PTK yang dikemukakan Menurut Arikunto, (2008:16) mengemukakan secara garis besar terdapat empat tahapan yang dilalui : “(1) Perencanaan, (2) Pelaksanaan, (3) Pengamatan dan (4) Refleksi

Penelitian ini menggunajan dua siklus, dimana setiap siklus terdiri dari 4 tahap yang akan dijelaskan sebagai berikut. Kegiatan yang dilakukan dalam tahap perencanaan adalah:

1. Menyusun rencana pembelajaran yang akan disampaikan kepada siswa.

2. Mempersiapkan materi ajar dengan pokok bahasan keadaan sosial negara-negara tetangga.

3. Merancang pembagian beberapa kelompok.
4. Mempersiapkan media pembelajaran yang sesuai dengan materi pembelajaran.

5. Membuat lembar observasi aktivitas guru dan siswa dalam pembelajaran.

6. Menyusun alat test/soal yang akan diberikan pada siswa berdasarkan kompetensi dasar yang dipelajari.

Pada tahap pelaksanaan, kegiatan yang dilaksanakan yaitu:

1. Guru menyampaikan tujuan pembelajaran dan menjelaskan materi keadaan sosial negaranegara tetangga.

2. Guru membagi siswa dalam beberapa kelompok yang beranggotakan 3-5 orang dan kepada setiap anggota kelompok diberi nomor 1 sampai 5.

3. Guru memberi soal dan masingmasing kelompok mengerjakannya.

4. Siswa menyatukan pendapatnya terhadap jawaban pertanyaan itu dan memastikan tiap anggota mengetahui jawaban tersebut.

5. Guru memanggil salah satu nomor, siswa dengan nomor yang dipanggil melaporkan hasil kerjasama mereka.

6. Kelompok lain diberikan kesempatan untuk menanggapi jawaban dari kelompok yang sudah mempersentasikan hasil diskusi 
7. Guru dan siswa menimpulkan hasil diskusi.

8. Guru memberi penilaian kepada siswa/kelompok.

Observasi dilakukan terhadap aktifitas siswa dan kinerja guru selama pembelajaran model Numbered Heads Together (NHT) dalam pembelajaran IPS berlangsung. Pengamatan ini bertujuan untuk mengetahui kesesuaian tindakan dengan rencana yang telah disusun guru. Pada tahap ini kegiatan yang dilakukan adalah melakukan pengamatan terhadap guru dalam proses tindakan dan kegiatan belajar siswa serta mengamati kondisi dan situasi saat proses pembelajaran berlangsung.

Kegiatan refleksi dilakukan untuk melihat perkembangan pelaksanaan serta memperoleh kesimpulan dari tindakan siklus I yang telah dilakukan dan apabila pelaksanaan siklus I belum tuntas berdasarkan indikator keberhasilan dan perolehan data dari hasil pengamatan maka hasil refleksi ini kemudian digunakan sebagai dasar untuk tahap perencanan pada siklus II.

Pengumpulan data dilakukan melalui tahap sebagai berikut:

1. Tes Hasil Belajar

Tes yang digunakan untuk mendapatkan data hasil belajar siswa yaitu berupa tes hasil belajar IPS siswa di dalam kelas. Tes digunakan untuk memperoleh data tentang kemampuan peserta didik pada beberapa materi pokok keadaan sosial negara-negara tetangga. Tes ini diberikan pada setiap akhir siklus untuk memperoleh data tentang hasil belajar siswa. Tes yang diberikan adalah tes dalam bentuk pilihan ganda dengan jumlah soal sepuluh. Adapun tes yang digunakan sesuai dengan kurikulum dan tujuan yang ingin dicapai.

\section{Observasi}

Observasi dilakukan untuk mengetahui seluruh aktivitas yang terjadi selama pembelajaran. Teknik ini merekam secara langsung dan tidak langsung kegiatan-kegiatan yang sedang terjadi. Obervasi yang dilakukan merupakan pengamatan terhadap seluruh kegiatan pembelajaran dan perubahan yang terjadi pada saat dilakukannya pemberian tindakan.

Data deskriptif kuantatif diperoleh dengan menggunakan (tes awal, protes siklus I dan protes siklus II). Penelitian ini lebih memperhatikan kualitas hasil dan keterkaitan antara kegiatan yaitu hasil belajar siswa pada pelajaran IPS dengan menggunakan model Numbered Heads Together.

Untuk mengukur tingkat atau persentase daya serap pada materi 
pelajaran secara individual digunakan rumus sebagai berikut:

$$
S K=B-\frac{S}{0-1}
$$

Ket :

SK = Skor yang diperoleh siswa

$\mathrm{B}=$ Jawaban yang benar

$\mathrm{S}=$ Jawaban yang salah

$\mathrm{O}=$ Option

Adapun untuk penilaian hasil belajar, dapat dihitung dengan rumus: $P H B=\frac{\text { Skor yang diperoleh siswa }}{\text { Skor Maksimal }} \times 100$

Kriteria:

$<65=$ Siswa belum tuntas dalam belajar

$\geq 65$ = Siswa sudah tuntas dalam belajar

Dari uraian di atas dapat diketahui bahwa siswa belum tuntas atau sudah tuntas belajar dinilai secara individu. Selanjutnya untuk mengetahui apakah ketuntasan belajar siswa secara klasikal telah tercapai, dapat dilihat dari persentase siswa yang sudah tuntas dalam belajar.

Observasi dilakukan untuk mengetahui kesesuaian tindakan yang dilakukan dengan rencana yang telah disusun, sehingga dapat diketahui apakah pelaksanaan tindakan yang dilakukan menghasilkan perubahan sesuai dengan yang diinginkan. Cara mengolah data hasil observasi adalah:

Nilai Rata - rata $\frac{\text { JumlahSkor Observasi }}{\text { Jumlah Skor Maksimal }} \times 100$
Dengan kriteria sebagai berikut:

\begin{tabular}{|c|c|c|}
\hline No. & Nilai & Kriteria \\
\hline $\mathbf{1 .}$ & $0-59$ & Kurang \\
\hline $\mathbf{2 .}$ & $60-69$ & Cukup \\
\hline 3. & $70-89$ & Baik \\
\hline $\mathbf{4 .}$ & $90-100$ & Sangat Baik \\
\hline
\end{tabular}

\section{HASIL DAN PEMBAHASAN}

Sebelum perencanaan tindakan dilakukan, terlebih dahulu diberikan pre test kepada 27 orang siswa, dengan tujuan mengetahui kemampuan awal siswa dan juga untuk mengetahui letak kesulitankesulitan yang dialami siswa dalam menyelesaikan soal-soal tentang keadaan sosial negara-negara tetangga. Kemampuan awal siswa dapat dilihat pada tabel berikut:

Tabel 4.2 Distribusi Tingkat Hasil Belajar Pre Test Siswa

\begin{tabular}{|c|c|c|c|}
\hline Nilai & Frekuensi & $\begin{array}{c}\text { Persentase } \\
\text { \% }\end{array}$ & Keterangan \\
\hline 7 & 3 & $11,11 \%$ & Tidak Tuntas \\
\hline 20 & 4 & $14,81 \%$ & Tidak Tuntas \\
\hline 33 & 4 & $14,81 \%$ & Tidak Tuntas \\
\hline 47 & 7 & $25.92 \%$ & Tidak Tuntas \\
\hline 60 & 5 & $18,51 \%$ & Tidak Tuntas \\
\hline 73 & 4 & $14,81 \%$ & Tuntas \\
\hline \multicolumn{3}{|c|}{ Jumlah nilai } & $\mathbf{1 1 5 4}$ \\
\hline \multicolumn{3}{|c|}{ Jumlah siswa } \\
\hline \multicolumn{3}{|c|}{ atata nilai } & $\mathbf{4 2 , 7 4}$ \\
\hline
\end{tabular}

Pada tabel 4.2 di atas maka dapat diketahui bahwa nilai pretest dari 27 siswa sebelum dilakukan pembelajaran pada mata pelajaran IPS menunjukkan bahwa terdapat sebanyak 23 orang siswa tidak tuntas, 
sedangkan 4 orang siswa yang tuntas menyelesaikan tes awal.

Dari hasil pre test diperoleh tingkat ketuntasan belajar siswa secara klasikal dapat dihitung dengan rumus:

$$
P K K=\frac{\sum \text { Siswa yang tuntas }}{\sum \text { Siswa }} \times 100 \%
$$

Siswa yang tuntas sebesar $14,81 \%$ sedangkan siswa yang belum tuntas adalah $85,18 \%$. Dengan demikian dapat dikatakan bahwa siswa belum memahami materi keadaan sosial negara-negara tetangga, hal itu diakibatkan karena guru kurang melibatkan siswa selama proses pembelajaran dan kemampuan siswa dalam menyelesaikan soal-soal masih rendah sehingga pembelajaran dikategorikan belum tuntas.

\section{Berdasarkan}

kesulitan-

kesulitan yang dihadapi siswa maka guru membuat alternatif pemecahan masalah, yaitu dengan menggunakan model pembelajaran Numbered Heads Together, yaitu dengan cara menyusun rencana pelaksanaan pembelajaran kemudian mempersiapkan materi ajar dengan pokok bahasan keadaan sosial negaranegara tetangga, merancang pembagian beberapa kelompok, mempersiapkan media pembelajaran yang sesuai dengan materi pembelajaran, membuat lembar observasi aktivitas guru dan siswa dalam pembelajaran, menyusun alat test/soal yang akan diberikan pada siswa berdasarkan kompetensi dasar yang dipelajari.

Pada tahap ini guru menerapkan model pembelajaran Numbered Heads Together. Pelaksanaan tindakan pada siklus I ini dilakukan sebanyak dua kali pertemuan. Tiap pertemuan berlangsung selama dua jam pelajaran (2 x 35 menit). Pada tahap ini peneliti melaksanakan kegiatan pembelajaran yang merupakan pengembangan dan pelaksanaan dari program pengajaran yang disusun pada tahap perencanaan yaitu guru menjelaskan tentang materi keadaan sosial negara-negara tetangga, guru membagi siswa kedalam kelompok kecil dan setiap anggota kelompok diberi nomor, guru mengajukan pertanyaan kepada siswa dan guru member kesempatan kepada siswa untuk menyatukan pendapatnya kemudian beberapa siswa dengan nomor yang dipanggil melaporkan hasil kerjasama mereka kedepan. Kemudian guru memberikan kesempatan kepada kelompok lain untuk menanggapi jawaban dari kelompok yang sudah mempersentasikan hasil diskusi. Setelah itu guru dan siswa bersamasama menyimpulkan materi pelajaran yang telah dipelajari.

Setelah pelaksanaan siklus I selesai, guru memberikan pos test (tes hasil belajar I) dengan tujuan melihat hasil belajar siswa yang telah 
diberikan tindakan dan guna mengetahui sudah sejauh mana pemahaman materi dan kemampuan siswa dalam menyelesaikan soal materi keadaan sosial negara-negara tetangga pada pelajaran IPS.

Observasi atau pengamatan dilakukan oleh guru kelas mulai dari awal pelaksanaan tindakan pembelajaran yang menerapkan penggunaan model pembelajaran Numbered Heads Together dalam pembelajaran IPS pada materi keadaan sosial negara-negara tetangga sebagai upaya peningkatan hasil belajar siswa.

Pada saat yang bersamaan pula peneliti diobserver oleh guru kelas untuk mengetahui konsistensi dalam melaksanakan pembelajaran dengan model pembelajaran Numbered Heads Together pada materi keadaan sosial negara-negara tetangga. Observer memberikan hasil bahwa kemampuan peneliti dalam memberikan materi

Berdasarkan hasil observasi yang dilakukan selama proses belajar mengajar yaitu didapat:

$$
N O=\frac{S O}{S M} \times 100
$$

(Sudjana Nana, 2009:133)

Dengan demikian hasil observasi tergolong dalam kategori cukup. Hanya saja pada penggunaan pendekatan kontekstual yang dilakukan guru kurang sesuai dengan kompetensi mengajar dan belum dilakukan secara sistematis, serta pemanfaatan waktu belum sesuai dengan yang diharapkan.

Berdasarkan data pada tabel maka dapat disimpulkan bahwa aktivitas siswa dalam mengikuti pembelajaran dengan menggunakan model Numbered Heads Together tergolong baik dengan nilai rata-rata yang diperoleh siswa secara klasikal 60,99. Dengan demikian maka pada siklus II diharapkan aktivitas siswa akan lebih baik lagi dalam mengikuti pembelajaran dengan model Numbered Heads Together sehingga diharapkan akan meningkatkan hasil belajar siswa pada materi keadaan sosial negara-negara tetangga. Berdasarkan hasil tes berupa tugas menyelesaikan soal tentang membentuk organisasi kelas setelah dilakukan tindakan I pada siswa melalui penggunaan metode pembelajaran inkuiri didapat data sebagai berikut:

\section{Tabel 4.6 Persentase Nilai Siklus I}

\section{Siswa}

\begin{tabular}{|c|c|c|c|}
\hline Nilai & $\mathbf{F}$ & Persentase \% & Keterangan \\
\hline 33 & 2 & $7,40 \%$ & Tidak Tuntas \\
\hline 47 & 4 & $14,81 \%$ & Tidak Tuntas \\
\hline 60 & 5 & $18,51 \%$ & Tidak Tuntas \\
\hline 73 & 9 & $33,33 \%$ & Tuntas \\
\hline 87 & 6 & $22,22 \%$ & Tuntas \\
\hline 100 & 1 & $3,70 \%$ & Tuntas \\
\hline \multicolumn{3}{|c|}{ Jumlah nilai } & 1833 \\
\hline \multicolumn{3}{|c|}{ Jumlah Siswa } & 27 \\
\hline \multicolumn{3}{|c|}{ Rata-rata nilai } & 67,88 \\
\hline
\end{tabular}


Pada tabel 4.6 di atas maka dapat dinyatakan bahwa kemampuan siswa dalam memahami materi keadaan sosial negara-negara tetangga sudah baik. Diketahui bahwa nilai siklus I dari 27 orang siswa, 16 orang siswa yang mencapai tingkat ketuntasan belajar, sedangkan 11 orang siswa belum mencapai tingkat ketuntasan belajar.

Dari hasil post test I diperoleh tingkat ketuntasan belajar siswa secara klasikal adalah 59,25\% sedangkan siswa yang belum memenuhi ketuntasan adalah 40,74\%. Dengan demikian dari hasil pretest dan post test I diperoleh peningkatan persentase ketuntasan belajar secara kalsikal sebesar $44,44 \%$. Selanjutnya hasil post test I digunakan sebagai bahan acuan dalam memberikan tindakan pada siklus II guna mengatasi kesulitan-kesulitan yang dialami siswa dalam menyelesaikan soal-soal materi keadaan sosial negara-negara tetangga.

Dari post test I diperoleh kesulitan yang dialami siswa yaitu: 1) Siswa kurang mengerti dengan model pembelajaran Numbered Heads Together. 2) Banyaknya siswa yang bermain-main saat melakukan diskusi kelompok, dan siswa kurang aktif selama proses belajar mengajar. 3) Siswa mengalami kesulitan dalam memahami materi keadaan sosial negara-negara tetangga. 4) Siswa kurang teliti dalam mengerjakan soalsoal multiple choise (pilihan berganda).

Berdasarkan data tersebut di atas dapat disimpulkan bahwa hasil belajar siswa dari 27 orang siswa masih tergolong rendah, maka perlu dilakukan perbaikan kegiatan pembelajaran guna meningkatkan hasil belajar siswa. Langkah yang diambil adalah melanjutkan proses belajar mengajar pada siklus II dengan mempertimbangkan letak kesulitan-kesulitan siswa dalam memahami soal-soal khususnya pada pokok bahasan keadaan sosial negaranegara tetangga.

Berdasarkan ketuntasan belajar siswa tersebut diperoleh persentase ketuntasan klasikal sebesar $59,25 \%$ atau 16 orang siswa. Pada siklus I ini terjadi peningkatan hasil belajar siswa sebesar 44,44\% dari pretest sebelumnya. Walaupun demikian keberhasilan proses belajar mengajar pada siklus I secara klasikal belum tercapai. Oleh karena itu perlu dilakukan perbaikan pembelajaran yang diharapkan dapat meningkatkan hasil belajar siswa maka dilanjutkan dengan pelaksanaan siklus II.

Siklus II dilaksanakan karena aktifitas dan hasil belajar siswa masih rendah pada siklus I. Pada siklus II, upaya yang dilakukan adalah mengoptimalkan pembelajaran dengan penerapan model pembelajaran Numbered Heads 
Together. Pada siklus ini, dilakukan tanya jawab antar kelompok dan memberikan kesempatan kepada siswa untuk melakukan kegiatan secara mandiri. Dalam diskusi kelompok guru harus sering memantau dan membimbing siswa dalam kelompok. Hal ini bertujuan untuk lebih mengaktifkan siswa di dalam kelompoknya dan siswa yang memiliki kemampuan lebih tinggi berusaha membantu siswa tersebut sehingga dapat mengerjakan soal dengan benar.

Peneliti melaksanakan
kegiatan belajar mengajar
berdasarkan rencana kegiatan melalui
model pembelajaran Numbered Heads
Together yang didukung dengan metode tanya jawab dan latihan soalsoal kegiatan pembelajaran yang dilakukan. Pada tahap ini peneliti melaksanakan kegiatan yaitu dengan cara menyusun rencana pelaksanaan pembelajaran kemudian mempersiapkan materi ajar dengan pokok bahasan keadaan sosial negaranegara tetangga, merancang pembagian beberapa kelompok, mempersiapkan media pembelajaran yang sesuai dengan materi pembelajaran, membuat lembar observasi aktivitas guru dan siswa dalam pembelajaran, menyusun alat test/soal yang akan diberikan pada siswa berdasarkankompetensi dasar yang dipelajari. Setelah tindakan pada siklus II selesai, kemudian diberikan post test II yang bertujuan untuk mengetahui hasil belajar siswa pada pokok bahasan keadaan sosial negaranegara tetangga.

Pelaksanaan tindakan pada siklus II ini dilakukan sebanyak dua kali pertemuan. Tiap pertemuan berlangsung selama dua jam pelajaran ( $2 \times 35$ menit). Pada tahap ini peneliti melaksanakan kegiatan pembelajaran yang merupakan pengembangan dan pelaksanaan dari program pengajaran yang disusun pada tahap perencanaan yaitu guru menjelaskan tentang materi keadaan sosial negara-negara tetangga, guru membagi siswa kedalam kelompok kecil dan setiap anggota kelompok diberi nomor, guru mengajukan pertanyaan kepada siswa dan guru memberi kesempatan kepada siswa untuk menyatukan pendapatnya kemudian beberapa siswa dengan nomor yang dipanggil melaporkan hasil kerjasama mereka kedepan. Kemudian guru memberikan kesempatan kepada kelompok lain untuk menanggapi jawaban dari kelompok yang sudah mempersentasikan hasil diskusi. Setelah itu guru dan siswa bersamasama menyimpulkan materi pelajaran yang telah dipelajari.

Setelah pelaksanaan siklus II selesai, guru memberikan pos test (tes hasil belajar II) dengan tujuan melihat hasil belajar siswa yang telah diberikan tindakan dan guna mengetahui sudah sejauh mana 
pemahaman materi dan kemampuan siswa dalam menyelesaikan soal materi keadaan sosial negara-negara tetangga pada pelajaran IPS.

Observasi dilakukan oleh guru mulai dari awal pelaksanaan tindakan sampai akhir pelaksanaan tindakan. Dari hasil observasi yang dilakukan diperoleh hasil bahwa proses pembelajaran sudah baik. Hal ini terlihat bahwa siswa semakin aktif belajar, khususnya bagi siswa yang kurang paham. Siswa dalam tiap kelompok saling membantu dalam menyelesaikan LKS yang diberikan guru serta siswa semakin percaya diri dalam mempersentasikan hasil kerja kelompok mereka di depan kelas.

Berdasarkan hasil observasi yang dilakukan selama proses belajar mengajar yaitu didapat:

$$
\begin{aligned}
& N O=\frac{S O i}{S M} \times 100 \text { maka } \\
& N O=\frac{62}{68} x 100=91,17
\end{aligned}
$$

(Sudjana Nana, 2009:133)

Dengan demikian hasil observasi tergolong dalam kategori sangat baik. Artinya proses belajar mengajar dengan menggunakan model Numbered Heads Together sudah dijalankan secara maksimal.

Dari hasil observasi yang dilakukan, diketahui bahwa aktivitas siswa dalam mengikuti pembelajaran dengan menggunakan model Numbered Heads Together sangat baik dengan nilai rata-rata yang diperoleh siswa secara klasikal 82,16. Dengan demikian, peneliti menyimpulkan bahwa hasil belajar siswa dari aspek afektif dan psikomotornya pada materi keadaan sosial negara-negara tetangga akan lebih baik ketika mengikuti pembelajaran dengan model Numberde Heads Together. Berdasarkan hasil observasi pada siklus II, peneliti berupaya mempertahankan dan meningkatkan proses belajar mengajar dengan model pembelajaran Numbered Heads Together. Peneliti telah berhasil memotivasi siswa yang mengalami kesulitan dalam mengerjakan soalsoal serta siswa sudah memahami materi keadaan sosial negara-negara tetangga.

Pada akhir siklus II, siswa diberikan tes hasil belajar yang bertujuan untuk mengetahui tingkat keberhasilan atas tindakan yang diberikan. Ketuntasan hasil belajar siswa pada siklus II ini dapat dilihat pada table berikut:

Tabel 4.10 Persentase Nilai Siklus

\begin{tabular}{|c|c|c|c|}
\hline Nilai & $\mathbf{F}$ & Persentase & Keterangan \\
\hline 47 & 1 & $3,70 \%$ & Tidak Tuntas \\
\hline 60 & 2 & $7,40 \%$ & Tidak Tuntas \\
\hline 73 & 7 & $25,92 \%$ & Tuntas \\
\hline 87 & 8 & $29,62 \%$ & Tuntas \\
\hline 100 & 9 & $33,33 \%$ & Tuntas \\
\hline \multicolumn{3}{|c|}{ Jumlah nilai } & 2274 \\
\hline \multicolumn{3}{|c|}{ Jumlah siswa } & 27 \\
\hline \multicolumn{3}{|c|}{ Rata-rata nilai } & 84,22 \\
\hline
\end{tabular}
II Siswa 
Pada tabel 4.10 di atas maka dapat diketahui dari 27 orang siswa saat diberikan post test II terdapat sebanyak 3 orang siswa yang tidak tuntas, sedangkan 24 orang siswa telah mencapai tingkat ketuntasan belajar yang diharapkan. Hasil belajar siswa diambil berdasarkan nilai post test yang dilakukan pada siklus II, dari hasil penelitian diperoleh tingkat ketuntasan secara klasikal adalah $88,88 \%$ sedangkan siswa yang belum memenuhi ketuntasan adalah $11,11 \%$. Dengan demikian dari hasil post test I dan post test II diperoleh peningkatan persentase ketuntasan belajar secara kalsikal sebesar $44,44 \%$

Dari hasil analisis yang dilakukan pada siklus II ini terjadi peningkatan sebesar 29,63\% dengan tingkat ketuntasan belajar siswa secara kaliskal sebesar $88,88 \%$. Hasil ini menunjukan bahwa tindakan pembelajaran dengan menggunakan model pembelajaran Numbered Heads Together dapat meningkatkan hasil belajar siswa dalam materi pokok bahasan keadaan sosial negara-negara tetangga. Dengan melihat hasil post test II dapat diketahui bahwa siswa telah mencapai ketuntasan belajar secara klasikal sehingga tidak perlu melakukan perbaikan tindakan lagi.

Rekapitulasi nilai pre test, siklus I, dan siklus II dapat dilihat pada tabel di bawah Berdasarkan data pada tabel 4.11 di atas maka dapat diketahui bahwa pada pre test terdapat 4 orang siswa $(14,81 \%)$ yang mencapai tingkat ketuntasan secara klasikal dengan nilai rata-rata 42,74 , pada siklus I terdapat 16 orang siswa $(59,25 \%)$ yang mencapai tingkat ketuntasan klasikal dengan nilai ratarata 67,88 dan pada siklus II terdapat 24 orang siswa $(88,88 \%)$ yang mencapai tingkat ketuntasan klasikal dengan nilai rata-rata 84,22. Dengan demikian dapat disimpulkan bahwa terjadi peningkatan hasil belajar siswa setelah dilakukan pembelajaran dengan menggunakan model pembelajaran Numbered Heads Together pada pelajaran IPS di Kelas VI SD Negeri 060819 Medan Kota.

Berikut disajikan tabel peningkatan hasil belajar siswa pada pokok bahasan keadaan sosial negaranegara tetangga:

Tabel 4.12 Tabel Rata-Rata Hasil Belajar Siswa

\begin{tabular}{|c|c|c|}
\hline No & Jenis Tes & Rata-rata \\
\hline 1 & Pre Test & 42,74 \\
\hline 2 & Siklus I & 67,88 \\
\hline 3 & Siklus II & 84,22 \\
\hline
\end{tabular}

Tabel 4.13 Persentase Hasil Belajar Siswa

\begin{tabular}{|c|c|c|}
\hline No & Jenis Tes & Persentase (\%) \\
\hline 1 & Pre Test & $14,81 \%$ \\
\hline 2 & Siklus I & $59,25 \%$ \\
\hline 3 & Siklus II & $88,88 \%$ \\
\hline
\end{tabular}




\section{Pembahasan Hasil Penelitian}

Dengan menggunakan Model Pembelajaran Numbered Heads Together dapat meningkatkan hasil belajar siswa khususnya pada materi keadaan sosial negara-negara tetangga. Berdasarkan hasil penelitian, pada pretest yang dilakukan terhadap 27 orang siswa terdapat sebanyak 23 orang $(85,18 \%)$ yang mendapat hasil belajar rendah (tidak tuntas) dan sebanyak 4 orang $(14,81 \%)$ yang termasuk dalam kategori tuntas dalam belajar. Berdasarkan hasil penelitian ini, dapat dikatakan pretest yang diberikan peneliti kepada siswa menunjukan bahwa tingkat keberhasilan siswa pada materi keadaan sosial negaranegara tetangga tergolong rendah.

Beberapa kesulitan yang dihadapi siswa yaitu: 1) Keterbatasan sumber belajar, contohnya bukubuku, gambar-gambar yang dapat membantu siswa untuk memahami materi yang diajarkan, 2) Keterbatasan guru dalam penguasaan model pembelajaran, dalam pembelajaran guru menggunakan metode ceramah sehingga sangat membosankan bagi siswa, 3) Siswa kurang cermat dan teliti dalam menyelesaikan soal-soal multiple choise (pilihan berganda). Oleh karena itu data hasil temuan ini dapat dijadikan acuan untuk melakukan tindakan dengan menggunakan model pembelajaran Numbered Heads
Together. Setelah pemberian tindakan melalui pembelajaran Numbered Heads Together pada siklus I terdapat 11 orang $(40,74 \%)$ siswa yang belum tuntas dalam pembelajaran dan 16 orang $(59,25 \%)$ siswa yang tuntas dalam pembelajaran. Ini menunjukan terjadi peningkatan sebesar 44,44\% dari hasil tes sebelumnya. Kesulitan yang dialami siswa pada siklus ini yaitu: 1) Siswa kurang mengerti dengan model pembelajaran Numbered Heads Together. 2) Banyaknya siswa yang bermain-main saat melakukan diskusi kelompok, dan siswa kurang aktif selama proses belajar mengajar. 3) Siswa mengalami kesulitan dalam memahami materi keadaan sosial negara-negara tetangga. 4) Siswa kurang teliti dalam mengerjakan soal-soal multiple choise (pilihan berganda).

Upaya yang dilakukan peneliti untuk mengatasi kesulitan dalam PBM agar hasil belajar lebih meningkat yaitu pada siklus II dilakukan tanya jawab dalam diskusi kelompok dan memberikan kesempatan kepada siswa untuk mengeluarkan pendapatnya. Hal ini bertujuan untuk lebih mengaktifkan siswa dan saling membantu dalam kelompok. Guru juga memotivasi siswa dan melibatkan siswa dalam pembejaran. Dengan cara ini materi yang diajarkan lebih mudah dipahami.

Dari hasil belajar ang diperoleh siswa pada siklus II, 
terdapat sebanyak 3 orang $(11,11 \%)$ siswa yang tidak tuntas dalam belajar sedangkan 24 orang $(88,88 \%)$ siswa yang termaksud kedalam kategori tuntas. Jika dibandingkan pada siklus I terjadi peningkatan sebesar $29,63 \%$. Dengan demikian dapat dikatakan bahwa siswa dapat memahami materi keadaan sosial negara-negara tetangga. Hal ini dapat dilihat dari hasil belajar siswa pada siklus II sebesar $88,88 \%$.

Dengan melakukan tindakan melalui model pembelajaran Numbered Heads Together di Kelas VI SD Negeri 060819 Medan Kota.pokok bahasan keadaan sosial negara-negara tetangga dapat meningkatkan hasil bel;ajar siswa, setiap siswa lebih termotivasi belajar karena siswa terlibat aktif dalam proses pembelajaran.

\section{SIMPULAN}

Setelah kita membahas beberapa hal, baik yang berupa teori maupun yang berupa temuan hasil dari lapangan, maka dalam bagian ini tibalah saatnya peneliti untuk mengambil suatu kesimpulan yang barang kali bisa kita gunakan untuk mengemukakan suatu saran, guna meningkatkan kualitas pendidikan terutama pendidikan IPS. Beberapa kesimpulan yang dapat ditarik dari hasil penelitian ini adalah:

1. Pada pre tes dari 27 orang siswa Kelas VI SD Negeri 060819
Medan Kota terdapat 4 siswa yang tergolong tuntas dengan PKK = $14,81 \%$ dan 23 siswa $\mathrm{PKK}=$ $85,18 \%$ siswa yang tergolong tidak tuntas.

2. Pada siklus I hasil yang dicapai tidak sesuai dengan target ketercapaian nilai, dari 27 orang siswa kelas VI SD Negeri 060931 Medan Kota terdapat 16 siswa yang tergolong tuntas dengan $\mathrm{PKK}=59,25 \%$ dan 11 siswa yang tergolong tidak tuntas $\mathrm{PKK}=$ $40,74 \%$. Terdapat $44,44 \%$ dari pretes $14,81 \%$ sampai siklus I $59,25 \%$, maka perlu dilanjutkan penelitian pada siklus II.

3. Pada siklus II hasil yang diperoleh sudah sangat menggembirakan dan sudah mencapai nilai yang ditargetkan. Nilai yang diperoleh pada siklus II adalah 24 orang siswa sudah mencapai pada kategori sangat baik dengan $\mathrm{PKK}=88,88 \%$ dan 3 orang siswa yang termaksud pada kategori cukup yaitu dengan $\mathrm{PKK}=11,11 \%$ yang masih tergolong rendah. Setelah diadakan penelitian, siswa yang rendah ini lambat menerima pelajaran, jadi pembelajaran yang dilakukan hanya sampai kepada siklus II.

4. Selanjutnya dari hasil data observasi pada siklus I kegiatan guru dalam mengajar diperoleh nilai rata-rata 69,11 dan kegiatan 
Onike Naibaho: Penerapan Model Numbered ..

siswa selama mengikuti pembelajaran memperoleh nilai rata-rata $63,6 \%$ termaksud kategori cukup, umtuk itu perlu dilanjutkan kembali observasi pada siklus II.

5. Ternyata terjadi peningkatan dimana kegiatan guru dalam mengajar pada siklus II memperoleh nilai rata-rata 91,17 dan kegiatan siswa selama mengikuti pelajaran memperoleh nilai rata-rata $88,6 \%$ termaksud kategori sangat baik.

Dari hasil penelitian dan kesimpulan di atas maka guru mengajukan saran sebagai berikut:

1. Guru diharapkan menerapkan model pembelajaran Numbered Heads Together sebagai alternatif dalam kegiatan pembelajaran karena model pembelajran ini dapat meningkatkan hasil belajar siswa pada mata pelajaran IPS khususnya materi keadaan sosial negara-negara tetangga dan dapat memotivasi siswa serta melatih siswa untuk belajar aktif.

2. Bagi pihak sekolah agar kiranya dapat menambah pengadaan sarana dan prasarana pelajaran, serta melakukan penelitian kepada guru-guru menambah pengetahuan tentang penggunaan model pembelajaran yang dapat meningkatkan kenapuan guru sehimgga hasil belajar siswa dapat ditingkatkan khususnya model
Numbered Heads Together dan banyak model lainnya agar tidak membosankan bagi siswa.

3. Bagi peneliti berikutnya jika ingin melakukan jenis penelitian yang sama sebaiknya dilaksanakan lebih dari satu siklus, agar tercapai hasil belajar yang lebih efektif dan efesien

\section{DAFTAR RUJUKAN}

AM, Sardiman. 2011. Interaksi dan Motivasi Belajar-Mengajar. Jakarta: Raja Grafindo Persada.

Arikunto, Suharsimi, dkk. 2010. Penelitian Tindakan Kelas. Jakarta: Bumi Aksara.

Aqib, Zainal. 2011. Penelitian Tindakan Kelas. Bandung: CV. Yrama Widya.

Dimyanti. 2009. Belajar dan Pembelajaran. Jakarta: Rineka Cipta.

Huda, Miftahul. 2011. Cooperative Learning. Yogyakarta: Pustaka Belajar.

Istarani. 2011. 58 Model Pembelajaran Inovatif. Medan: ISCOM Medan.

Purwanto. 2009. Evaluasi Hasil Belajar. Yogyakarta: Pustaka Pelajar.

Sapriya. 2009. Pendidikan IPS. Bandung: PT Remaja Rosdakarya. 
Slameto. 2010. Belajar dan Faktor Faktor yang Mempengaruhinya. Jakarta:

Rineka Cipta.

Suprijono, Agus. 2010. Cooperative Learning. Surabaya: Pustaka Pelajar.
Trianto. 2009. Mendesain Model Pembelajaran InovatifProgresif. Jakarta: Kencana Prenada Media Group.

Trianto. 2010. Model Pembelajaran Terpadu. Jakarta: BumiAksara. 